\title{
THE PEARL BUTTON INDUSTRY OF MUSCATINE, IOWA
}

\author{
By Mrs. Frances Schreurs Hurd
}

Frances Schreurs Hurd is the great-granddaughter of pioneer Iowans who arrived in Muscatine in 1846. She was educated in the Muscatine schools and at the University of Iowa, where she majored in Journalism and English. While attending the University, she met her husband, Marshall B. Hurd, who is Chief Engineer of the Iowa Public Service Company. They have lived in Sioux City for the past thirty-tluree years. The Hurds have one son, Gordon, who is with the General Electric Company and presently located at NASA headquarters near Houston, Texas.

The pearl button is perhaps the only article of clothing having its birth and growth in water. While still manufactured in smaller quantities as a luxury item, it reached a peak of production in Muscatine, Iowa, during the first third of the 20th century. After approximately 1930, the abundant supply of material and cheap labor in Japan undermined the fresh water pearl button industry. The development of inexpensive plastic discs make synthetics the chief source of buttons for clothing today.

The history of the Iowa pearl button began in Muscatine in 1890, with John F. Boepple, a German immigrant. Legend says that he cut his foot on a clam shell while swimming in the Mississippi River. He had made buttons from horn in Europe and noticed that the texture and color of the shell made it appear suitable for buttons. He gathered some shells and, after cutting a few buttons in his home with crude equipment, reportedly sold a dozen to a local merchant for ten cents.

Mr. Boepple contrived a set of hooks which he dragged across the river bottom and easily collected a boat load of 
clams. The clam senses a nearby foreign object and closes its shell over the hook, thus acting in self protection, but actually catching itself. These three-pronged hooks were called "crowfoot" and occasioned an amusing incident told by my father, Paul R. Schreurs, a pioneer in the industry. His clam digging crews were running out of supplies when he visited their camp on the Wabash River in Indiana, so he placed a long distance call over the local party line. After hearing a series of receivers being removed to "listen in" on his conversation, he ordered 10,000 "crow-feet," when a woman's voice interrupted: "That man's crazy! Who ever heard of wanting 10,000 crow's feet!"

After Mr. Boepple caught his original load of clams, he threw them in boiling water to force open the shells. After boiling and removing the meat, on the river bank, he hauled the shells home in his wagon and fashioned a few more buttons which he soon sold. Realizing the possibilities, he tried to find capital, but Muscatine was a lumber town in 1890, and not interested.

He was finally loaned $\$ 10.00$ by a Mr. Molis. With his new partner's interest, Mr. Boepple was able to acquire about $\$ 500.00$ worth of machinery. With the new equipment he turned out crude buttons which found a ready market in Muscatine at about half the price of Eastern or imported stock.

On a trip to the Eastern markets, Mr. Molis interested button men there and some of them journeyed west to Muscatine to investigate. This made Muscatine begin to appreciate its unsung inventor. With clam shells free for digging, the fresh water pearl button business was on with a rush. Men, women and children, old and young, joined in the scramble. The Mississippi was alive with boats. At night the river banks glowed with hundreds of fires as the diggers boiled their clams. Houseboats joined the land-based searchers and a thousand houseboats were built in one summer to add to the confusion.

Compounding the excitement, one digger found a pearl in a clam shell which he sold for $\$ 2,000.00$ to a Chicago jeweler. This news added zest to the search and brought in many new families as well as speculators. Elements were added that 
made the small Iowa town resemble a rough mining camp with fights and crimes an everyday occurrence. Everyone had the right to fish in a government stream, so only brains or muscle controlled the choice spots.

With every woodshed becoming a "factory," the result was chaos. Machines were inefficient, workmanship was poor and the bubble soon burst, leaving Mr. Boepple a poor and disillusioned man. However, mechanically minded men had been improving the machinery and three brothers who operated a small plumbing shop developed what they claimed to be an automatic machine. It reportedly would receive the blanks and turn them into finished buttons, patterned and drilled, ready for polishing. No one had the capital to purchase these machines, so the brothers offered them for rent at $\$ 1.00$ each per day. By 1900, the infant industry had gained new vigor as problems were solved and the product improved. In succeeding years, thousands were employed and output increased until approximately $\$ 1,500,000.00$ was paid for shells in the year 1913 alone. Finished products, including both buttons and pearls bought from diggers, were valued in the millions of dollars. As late as 1937, shells totaling 27,000 tons were dug in seventeen states to make 17,145,649 gross of buttons valued at $\$ 4,752,918.00$.

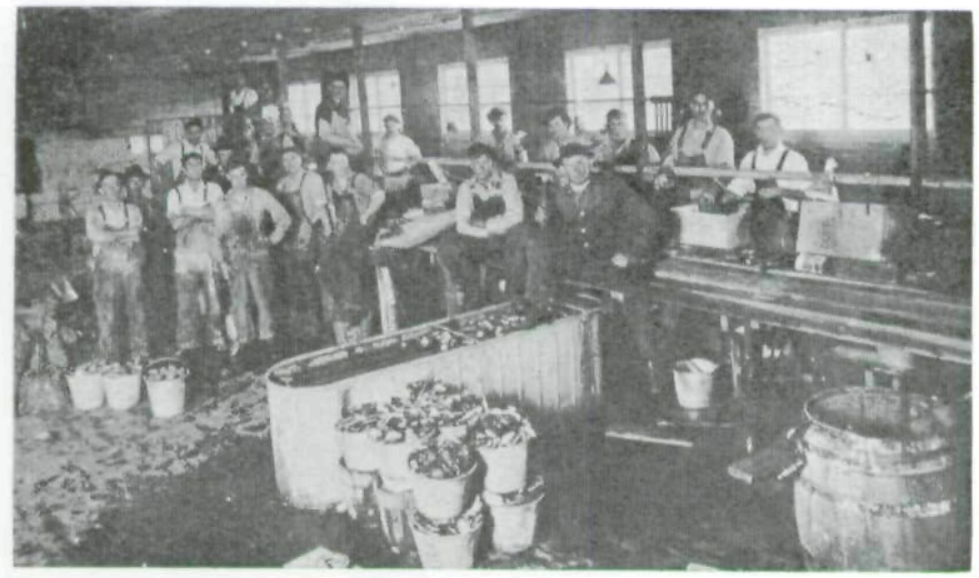

Pearl Button Factory in 1910 


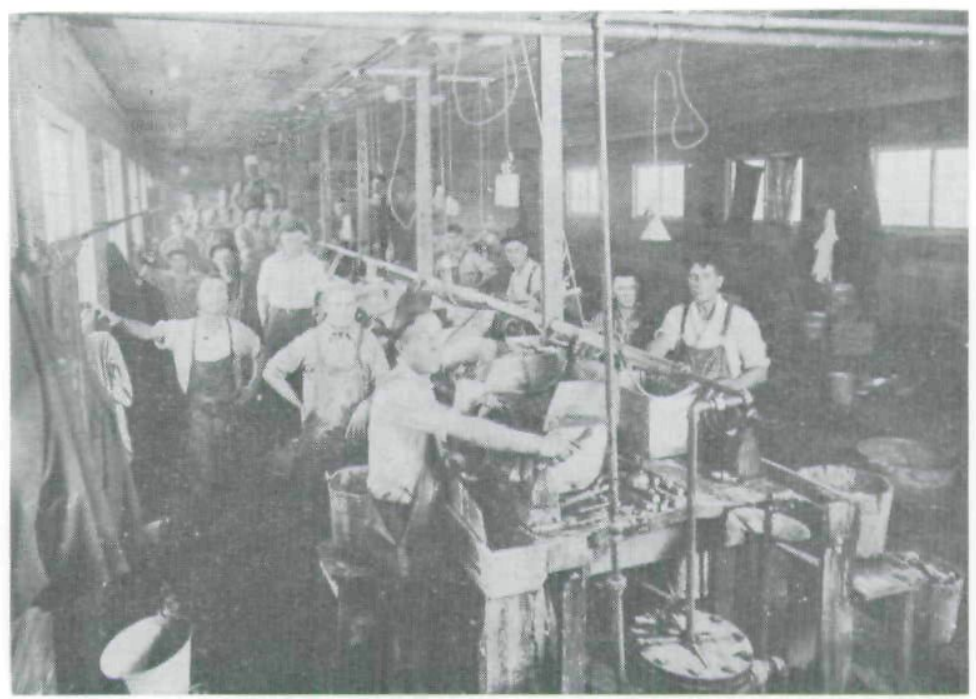

Pearl Button Factory in 1910

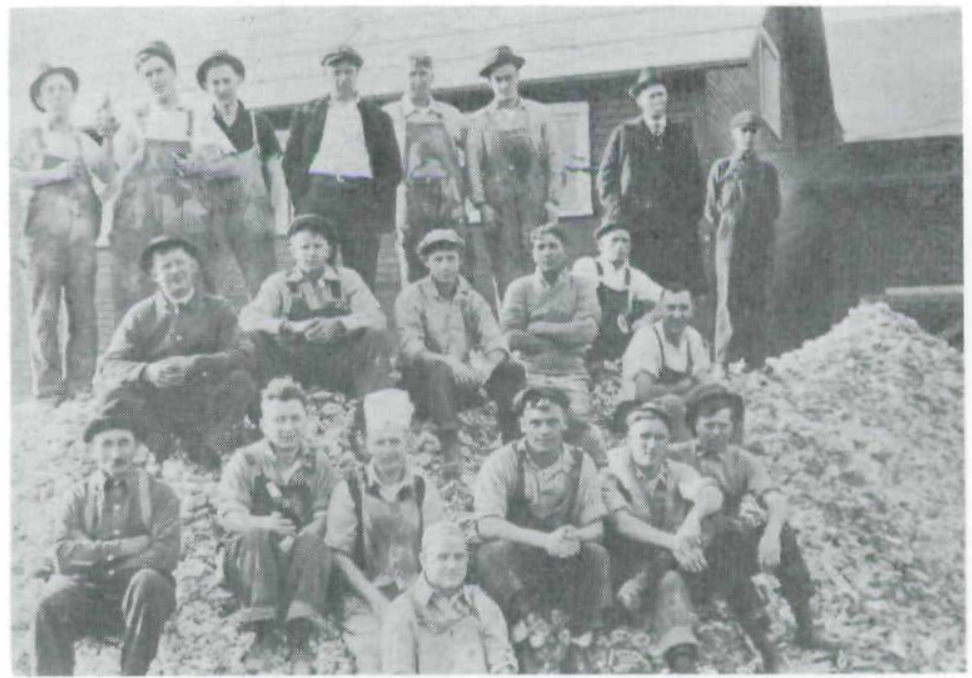

Factory Workers on Pile of Waste Shells in 1910. 
A brochure issued by the Hawkeye Pearl Button Company in 1913, lists material and gives instructions for building a shelling boat at a total cost between $\$ 7.00$ and $\$ 10.00$. Two sets of crowfoot bars, oars, oar locks and other necessities added another $\$ 9.83$. Thus a digger was in business with one boat for less than $\$ 20.00$ with crowfoot hooks available at 500 for $\$ 6.00$.

The boat was usually about three feet wide at the bottom and eighteen feet long. Two rods, or half-inch gas pipes, 14 feet long were elevated above the sides of the boat. To each rod were tied many lengths of trout line on each of which were fastened several crowfoot hooks. These rods were lowered into the water and dragged along the bottom by manilla ropes. When the weight or digger's instinct indicated, the rods were raised out of the water and hung on their supports heavy with clams and ready to be rowed into shore for the "boiling out." If the trout lines were spaced three inches apart on the bars and several hooks tied on at 12 inch intervals, a complete haul for one boat could be 700 clams.

Instructions followed for boiling out the meat, caring for the vat, and for recognizing the different grades of pearls that might be found in the clams. Pearls were usually sold to whoever would buy them and were divided into three classifications of "pearls," "baroques" and "slugs." Pearls had no standard value and the price was governed by size, shape and luster. They were sold by grain weight with four grains equaling one carat. Baroques were of irregular shape, but usually had one good side for mounting. This increased their value and they sold by grain weight equal to perfect pearls. Slugs were small, irregular pieces of all shapes and were sold by troy ounce weight, their value fluctuating according to demand. In 1913, unsorted slugs just as they came from the shells varied in price from $\$ 1.00$ to $\$ 4.00$ per ounce, depending on quality, color and shape. The 1964 price of a strand of fresh water pearls was quoted in a Des Moines Register article on December 13 , as being approximately $\$ 5,000.00$.

Shells used in the cutting of buttons included the yellow back, the warty back, the nigger head, the black sand shell, the mucket, the washboard, the pocket book, the three sidge 
or blue point, the pig toe, the buckhorn, the maple leak and the elephant's ear. Other usable shells were sometimes found in mixed loads of shells, but the above were considered preferable.

As the Mississippi supply of shells dwindled, nearby rivers became a source with streams in Illinois, Indiana, Arkansas and other mid-west states furnishing tons of shells. These were shipped by water or rail freight to Muscatine for processing.

After arriving at the factory, the shells were graded by size and species, then soaked in vats of water for several days to soften. In cutting the blank, the shell was held against a tubular saw which was gauged according to the button size desired. After the blanks were sorted for thickness, they were churned to minimize irregularity and ground to remove the outer bark and reduce them to uniform thickness. Next followed more days of soaking, after which the blanks were patterned and thread holes drilled on finishing machines. The complete buttons were then polished and dried by friction in a series of tumblers containing acid, pumice and finally sawdust. This operation is still followed today.

Pearl buttons are handled individually in every process except the polishing, a fact that contributes to the high cost of production. In addition, when the button is placed in the patterning or drilling machine, it not only is handled individually but care must be taken to place it right side up because the "top" or inside of the original shell possesses the color and luster. After polishing and drying, the nimble fingers of sorters inspect each button for quality, size, thickness, color and luster. The "carding" of finished buttons was a popular source of income for housewives, church groups or clubs.

At the height of the button industry there were a few firms which included the complete process in one factory, from cutting the blanks to finishing and carding the buttons. Other smaller, or branch, plants helped supply the huge quantity of blanks needed by the larger factories.

As a grand-daughter and daughter of two men who contributed to the button and shell industry, these personal facts seem pertinent. My grandfather, Garrett W. Schreurs, was the second generation of his family, who originally migrated to 
America from Holland in 1846, and became millers in Muscatine. He was granted patents relative to the flour milling business as early as 1876 and again in 1884 . He was the first proprietor of a Muscatine flour mill to install the rolling mill system, and many other innovations are credited to his ingenuity.

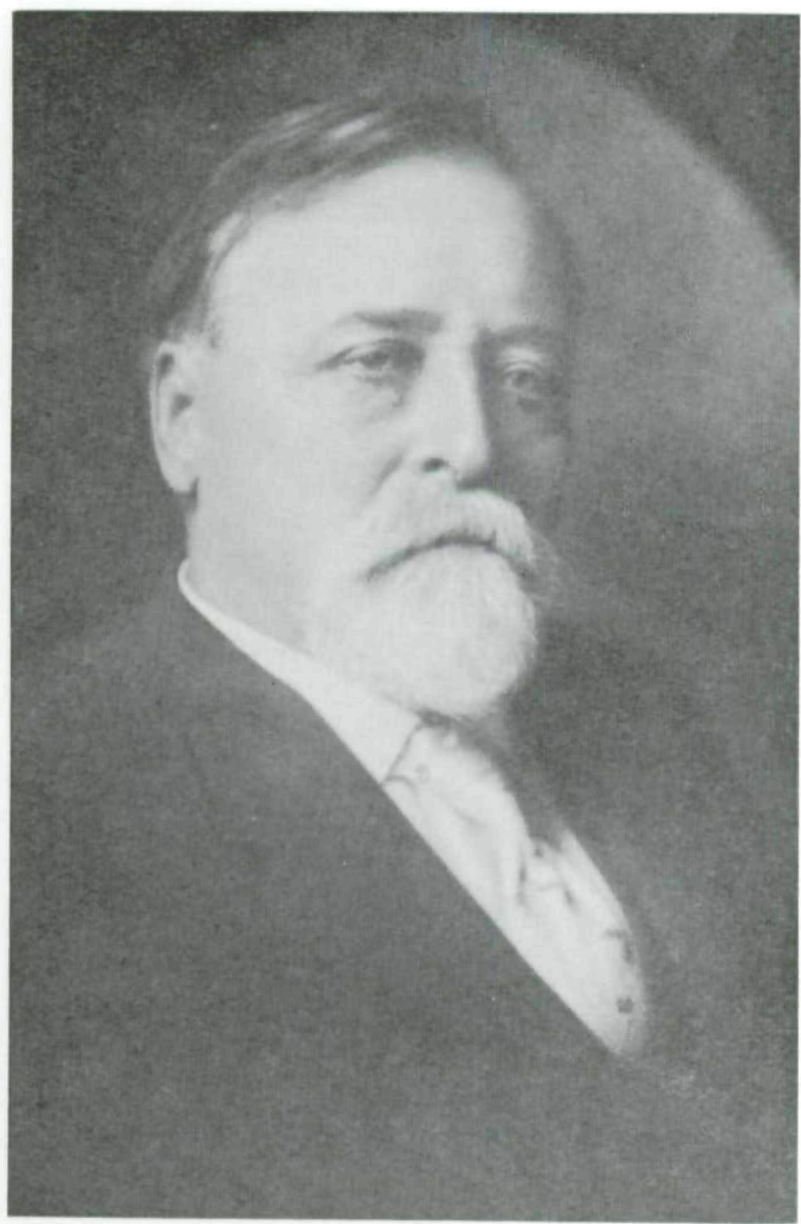

GARRETT W. SChreurs 


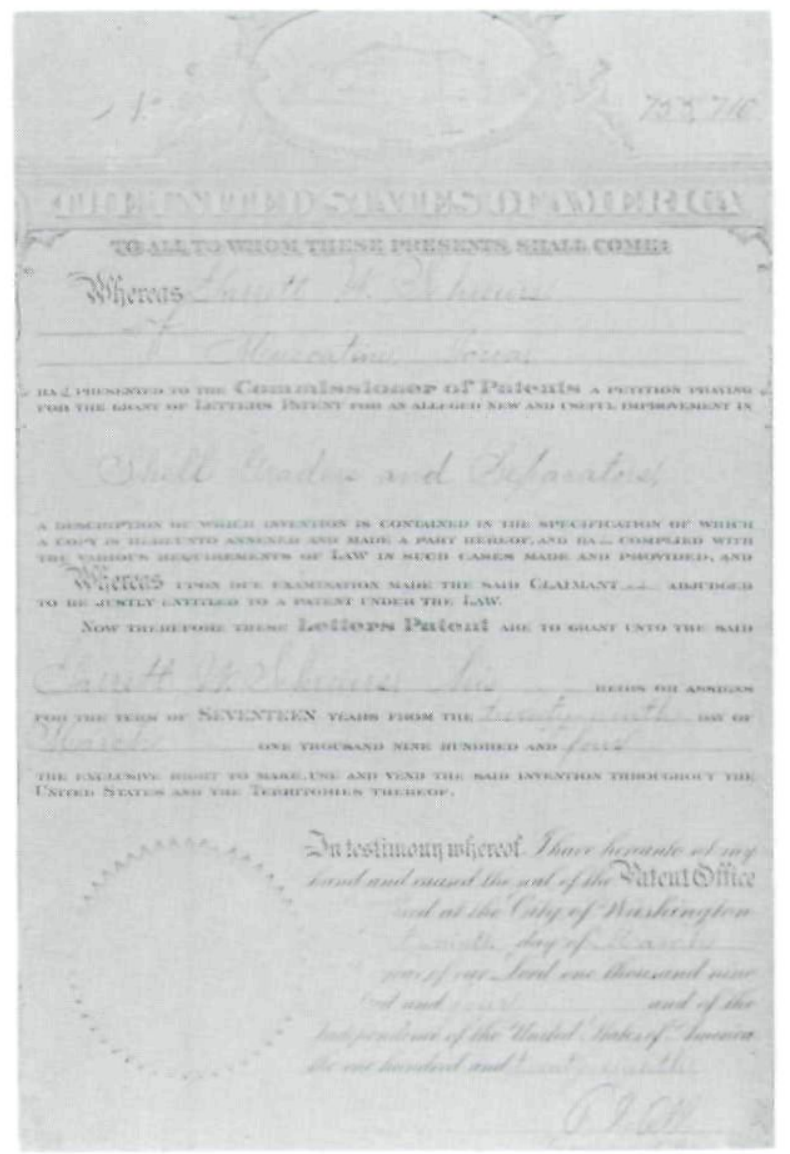

Patent for Shell Graders and Separators Issued to Garrett W. Schreurs.

Sensing the growth of the new pearl button industry, he and his son, Paul, retired from flour milling in 1900 and rented their Young America mill property to the Empire Pearl Button Company of New York. The buildings were converted for button cutting and Paul R. Schreurs managed the factory. His increasing activity in the industry stimulated his father's inventive mind, and Garrett Schreurs was granted several patents which benefitted the entire field. One of these covered a shell 
grander and separator which has never been improved upon and is still in use in its original form. There also were at least two patents which demonstrated improvements on the original button blank cutting machines. These particular patents were granted over a period from 1904 to 1911 and others were pending at the time of his death in 1915 .

Despite his being occupied primarily in one field of the business, Paul R. Schreurs was recognized for his fairness to

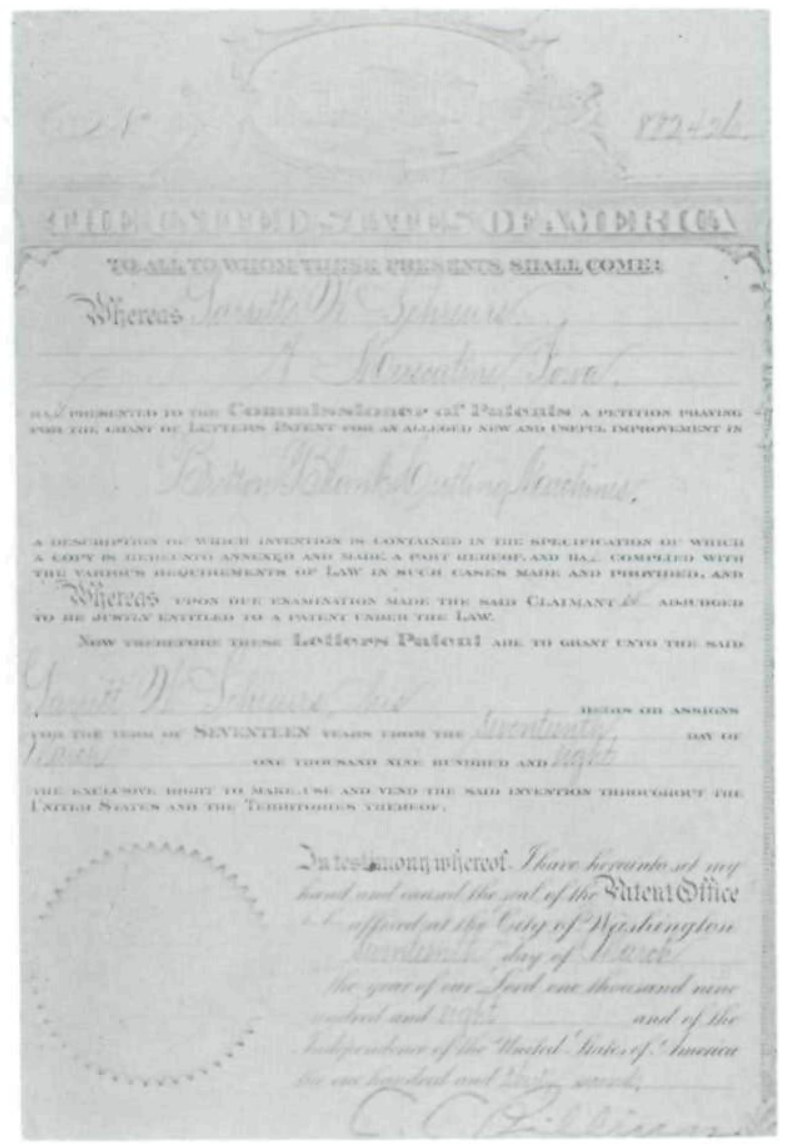

Patent for Button Blank Cutting Machines IsSUED to Garrett W. Schreurs. 
labor and was often called upon to mediate disputes in the industry. After withdrawal of the New York firm from Muscatine, Mr. Schreurs remained in the button cutting field until 1914, when he turned to the use of shells as by-products.

As in the early days of Mr. Boepple when the supply of shells seemed unlimited, Mr. Schreurs considered the mountains of waste shells piled up where ever blanks were cut. $\mathrm{He}$ developed machinery which ground the waste shells into several products. The largest screenings produced the colored and polished small shells and chips used by florists and in aquariums. The smaller size, unpolished, was used in stucco and cement products because of the lustrous gleam of the shell bits. The smallest particles became poultry and bird grit now recognized as a vital nutrient. This latter by-product was varied by the addition of oyster shell grit from the Gulf of Mexico, making it more palatable because of a slight saltiness. This product, alone, enabled shipment of eggs for greater distances because it hardened the shells and made them more resistant to breakage. The systematic feeding of this almost pure calcium improved nutrition over the former practice of allowing chickens to scratch for pebbles and natural grit in the barnyard.

The halycon days of the Muscatine fresh water pearl button industry are now part of history, although this fine quality button is still being made in smaller amounts for luxury trimmings. However, the bulk of serviceable buttons for clothing now are manufactured from Japanese sea shells and from plastic discs which are shipped in barrels to factories to be finished.

Another, but perhaps not final, use for clam shells is in the Japanese cultured pearl industry. Thousands of tons of clam shells are shipped annually to Japan for this purpose and a favorite source is the original one, the Mississippi River. The dense, firm quality of the mussel shell, when machined into tiny pellets and inserted into an oyster, provides the irritant necessary to produce a cultured pearl. In a natural pearl, a grain of sand accidentally seeps into the shell and becomes irritating. The oyster protects itself through the years by coating the sand with a secretion called nacre. The size of the 
pellet inserted by the Japanese craftsman determines how quickly the cultured pearl can be harvested, the slower the process the more valuable the gem. Thus Japan, which helped destroy the fresh water pearl button industry, may be instrumental in reviving clam digging.

\title{
THE CHANGING FACE OF IOWA
}

\author{
By LidA L. Greene \\ Librarian of Iowa State Historical Library
}

A year ago Capitol Avenue east of the State House in Des Moines was a quiet aging street. Its houses had been built 75 or 80 years ago when the State House was young and its golden dome breath-taking beyond belief to the State that had raised it.

Now the street is no more. Its green grass is uprooted, its trees wrenched from the earth. Its houses with fading, somnolent facades are gone. There is only bare, brown earth and the mound where another State Office building will one day stand.

This is no memorial for a bull-dozed street, though perhaps someone should write it. It is, instead, a reminder that the face of our State is changing. Man-made behemoths gouge away hills to route a free-way. Something called urban renewal is leveling blocks of dwellings and older business houses to make way for brave, new-world structures to come. A quarter of a century from now who is there to remember a fan light above an old door? Or a country road, velvet with dust, where roadside shrubs were festooned in fall with migrating Monarch butterflies?

This is why pictures are of such importance to the conservation of history. Why, in fact, there is a special welcome for any new collections arriving at the Iowa Department of History. We thought you would like to know about three that arrived recently. 
Copyright of Annals of Iowa is the property of State of Iowa, by \& through the State Historical Society of Iowa and its content may not be copied or emailed to multiple sites or posted to a listserv without the copyright holder's express written permission. However, users may print, download, or email articles for individual use. 